\title{
NÍVEIS DE FUNDAMENTAÇÃO DO SISTEMA FILOSÓFICO HEGELIANO
}

\section{Levels of foundation of the hegelian philosophical system}

Niveles de fundamentación del sistema filosófico hegeliano

\section{Resumo}

Este artigo tem como objeto de investigação os principais níveis de fundamentação enquanto momentos estruturantes do sistema filosófico hegeliano. No contexto filosófico da comemoração dos duzentos anos de publicação da Enciclopédia das Ciências Filosóficas, o objeto do trabalho é a reconstrução dos momentos estruturantes da passagem da Ciência da Lógica para a Filosofia da Natureza, da Filosofia da Natureza para a Filosofia do Espírito e dessas para a esfera do Espírito Absoluto. O artigo não tem como meta a discussão de tópicos intrínsecos à Ciência da Lógica ou à Filosofia do Espírito, mas visa à exposição de círculos da passagem dialética de uma esfera para a outra como um autodesenvolvimento sistemático qualitativo. Mesmo de caráter genérico, não aponta para a possível substantividade de uma parte do sistema, mas para as relações fundamentais entre os círculos. $O$ texto é perpassado por uma chave interpretativa da filosofia hegeliana no sentido de que não é formado por partes fixas e estanques, mas é articulado na perspectiva de relações fundamentais caracterizadoras das interfaces entre as esferas.

Palavras-chave: Ciência da Lógica. Sistema. Ideia. História. Espírito.

Doutor em Filosofia pela PUCRS e professor de Filosofia no IFIBE, Passo Fundo, RS, Brasil. https://orcid.org/0000-0002-4126-3961. E mail: joao@ifibe.edu.br 


\begin{abstract}
The article aims to investigate the main levels of foundation as structuring moments of the Hegelian philosophical system. In the philosophical context of the commemoration of the two hundred years of publication of the Encyclopaedia of Philosophical Sciences, the object of the work is the reconstruction of the structuring moments of passage from one sphere to the other. The text asks about the passage from the Science of Logic to the Philosophy of Nature, from the Philosophy of Nature to the Philosophy of the Spirit and from these to the sphere of the Absolute Spirit. The article does not aim at discussing a topic intrinsic to the Science of Logic or the Philosophy of the Spirit, but aims at exposing circles of dialectical passage from one sphere to the other as a systematic qualitative self-development. Even of a generic nature, it does not point to the possible substantivity of a part of the system, but to the fundamental relations between circles. The text is permeated by a key interpretive of the Hegelian philosophy in the sense that it is not formed by fixed and watertight parts, but is articulated in the perspective of fundamental relations.
\end{abstract}

Keywords: Logic Science. System. Idea. History. Spirit.

\title{
Resumen
}

El artículo tiene como objeto de investigación los principales niveles de fundamentación en sus etapas estructurantes del sistema filosófico hegeliano. En el contexto filosófico de la celebración de 200 años de la publicación de la Enciclopedia de las Ciencias Filosóficas, el objeto de esta investigación se constituye en la reconstrucción de los momentos de la estructuración del pasaje de la Ciencia de la Lógica para la Filosofía de la Naturaleza, de la Filosofía de la Naturaleza a la Filosofía del Espíritu, y de estas esferas a la esfera del Espíritu Absoluto. El artículo no pretende discutir un tema intrínseco a la Ciencia de la Lógica o Filosofía del Espíritu, sino que visa la exposición de círculos de pasaje dialéctica de una esfera a la otra como un autodesarrollo cualitativo sistemático. De carácter incluso genérico, no apunta a la posible substantividad de una parte del sistema, sino a las relaciones fundamentales entre los círculos. El texto se caracteriza por presentar una clave interpretativa de la filosofía hegeliana en el sentido de que no se compone de piezas fijas y de carácter hermético, sino que se articula desde la perspectiva de relaciones fundamentales caracterizadoras de las interfaces entre las diferentes esferas.

Palabras clave: Ciencia de la Lógica. Sistema. Idea. Historia. Espíritu. 


\section{Introdução}

No contexto da comemoração do bicentenário de publicação da Enciclopédia das Ciências Filosóficas de Hegel, o objeto deste artigo será evidenciar movimentos estruturantes desta obra na qual o filósofo esboça o seu sistema completo. Trata-se dos diferentes graus de fundamentação intrínsecos ao sistema a partir dos quais são esboçadas as relações fundamentais entre as esferas da Ciência da Lógica, da Filosofia da Natureza e da Filosofia do Espírito, inscrevendo a obra num círculo relacional fundamental. Nesta abordagem, será evidenciado o movimento da passagem de uma esfera para a outra no processo de universalização, de complexificação e de concretização que caracteriza o movimento dialético.

$\mathrm{O}$ artigo trata dos diferentes graus de fundamentação metódica efetivados na perspectiva das relações interesféricas integradoras da Ciência da Lógica, da Filosofia da Natureza e da Filosofia do Espírito, consideradas a partir do critério do desenvolvimento sistemático aberto. O objetivo será indicar os pontos de mediação entre uma esfera e outra com o propósito de expor o sistema hegeliano na perspectiva das relações globais que o constituem sistematicamente. O sistema filosófico, considerado a partir da unidade da Ideia absoluta e a diferenciação das múltiplas esferas particulares, adentra em sua estrutura dialética e nos sentidos multilaterais de exposição. O formato dialético do sistema hegeliano é composto pela estruturação interna própria de cada círculo, ao se constituir como unidade específica. É, igualmente, estruturado pelas múltiplas relações entre as esferas filosóficas em interação mútua, como também por movimentos globais de autodesenvolvimento que incluem vários movimentos de particularização e de universalização.

$O$ texto está construído em diferentes momentos, ao tentar aproximar os níveis de fundamentação internamente estruturantes do sistema hegeliano. O primeiro ponto a ser considerado é a passagem da Ciência da Lógica para a Filosofia da Natureza, como uma transição da racionalidade lógica para a exterioridade da Natureza, uma forma de particularização 
da razão que aparece em seu ser outro, em sua exterioridade. O segundo ponto a ser considerado é a passagem da Filosofia da Natureza para a Filosofia do Espírito, quando o sistema adentra nos campos do espírito subjetivo e objetivo. O terceiro ponto a ser exposto é a passagem do espírito objetivo para o Espírito absoluto, em cujo movimento o sistema filosófico estabelece relações esboçadas em várias mediações silogísticas. Com esta abordagem, procuramos formular os diferentes graus de efetividade do sistema hegeliano, no círculo da sua fundamentação interesférica.

Do ponto de vista metodológico, serão inseridos parágrafos da Introdução à Enciclopédia das Ciências Filosóficas, da Introdução à Filosofia da Natureza, da Introdução à Filosofia do Espírito e dos parágrafos finais que tratam do Espírito absoluto. Nos capítulos a seguir constam esses textos densos de Hegel e textos de vários estudiosos do sistema filosófico hegeliano. O raciocínio desenvolvido procura analisar tais textos e concatenar a lógica intrínseca dos mesmos. Em razão da complexidade da temática, este artigo é ainda superficial, motivando elaborações mais aprofundadas.

\section{Da Ciência da Lógica para a Filosofia da Natureza}

A Ciência da Lógica fecha o seu ciclo na Ideia absoluta, em que Hegel faz a síntese entre método e sistema, subjetividade e objetividade, Lógica e realidade. O fechamento de um círculo coincide com a abertura para outro, quando se estabelece a passagem da Ciência da Lógica para a Filosofia da Natureza. A Filosofia da Natureza não é a exterioridade da Lógica, como se aquela fosse totalmente estranha a esta, mas caracteriza a Lógica em sua exterioridade, em sua diferença. A Filosofia da Natureza resulta da exteriorização da Lógica em sua exterioridade material, e a Natureza representa a concretização da Lógica. Hegel caracteriza esta passagem:

A natureza mostrou-se como a ideia na forma do ser-outro. Visto que a ideia é assim como o negativo dela mesma ou exterior a si, assim a natureza não é exterior apenas relativamente ante esta ideia (e ante a existência subjetiva da mesma, o espírito), mas a 
exterioridade constituiu a determinação, na qual ela está como natureza (HEGEL, 1995, §247).

Na passagem para a Filosofia da Natureza, o paradoxo dela se baseia na radical diferença de exterioridade em relação à Ciência da Lógica. Trata-se de uma espécie de negatividade, porque a Ciência da Lógica estabelece a sua própria autofundamentação racional enquanto a Natureza não é portadora dessa autonomia e capacidade de autodeterminação. O paradoxo entre as duas esferas ainda se estende para a pura racionalidade e interioridade da Ciência da Lógica e a materialidade e exterioridade da Filosofia da Natureza. Esta radical diferença e exterioridade entre as duas esferas é superada com a determinação da Ideia no seu ser outro, enquanto a Filosofia da Natureza é determinada como exterioridade. Isto se dá porque esta não é concebida como uma bruta materialidade, como para a sociedade liberal moderna exploradora da Natureza, mas ela é vivificada por uma lógica intrínseca a partir da qual articula os seus próprios movimentos. Desta forma, a Filosofia da Natureza também é portadora de uma lógica interna evidenciada na sua estruturação nos capítulos da mecânica, da física e da orgânica.

Na Filosofia da Natureza, Hegel não trata da Natureza empírica e exterior, mas formula uma Filosofia da Natureza pressuposta por conhecimentos científicos oriundos da mecânica, da física, da química, da biologia de seu tempo, etc. A abordagem filosófica hegeliana supera todos os paradoxos e dualismos de sua época que separou Lógica e Natureza, Natureza e Espírito, para integrar no método dialético o que foi separado em seu tempo. Nesse formato, nenhuma esfera da Lógica e da Natureza será completamente autônoma e isolada, exatamente porque a passagem da primeira para a segunda compreende em si mesma a diferença radical, pois a Ideia lógica se exterioriza na Filosofia da Natureza, e a Natureza, nesse movimento de diferenciação, interioriza em si mesma as determinações conceituais provenientes da Lógica que aquela expõe a partir de sua determinidade. Ao sustentar, nesse movimento, há um coextensivo 
processo de exteriorização e de interiorização, pois a Ciência da Lógica se exterioriza na radical autodiferenciação da Natureza, como um caminho de ampliação e de complexificação. Na mesma medida, nessa diferenciação, a Lógica se torna propriamente racional na capacidade de determinação, de criação e de diferenciação expressas na intrínseca ligação entre Ciência da Lógica e Filosofia do Real. Por outro lado, a Natureza se torna Filosofia da Natureza ao interiorizar a significação lógica da Ciência da Lógica, impulsionada pelo conhecimento humano. Hegel continua:

A filosofia da natureza pertence ela própria a este caminho do
retorno; pois é ela que suprassume a separação da natureza e
do espírito e que proporciona ao espírito o conhecimento da
sua essência na natureza. Esta pois é a posição da natureza no
todo; sua determinidade consiste em que a ideia se determina a
si própria, isto é, coloca em si a diferença, coloca outro, mas de
modo que ela em sua indivisibilidade é bem infinita e confere e
entrega ao ser-outro toda sua plenitude. Deus permanece igual
a si mesmo em seu determinar; cada um desses momentos é, ele
próprio, a ideia total e tem de ser posto como totalidade divina.
O diferente pode-se aprender sob formas de três espécies; o
universal, o particular e o singular (HEGEL, 1995, §247, Zusatz).

Os textos de Hegel são compenetrados por questões coextensivamente sistemáticas e históricas. A Filosofia da Natureza suprassume a separação entre Natureza e Espírito, numa clara alusão de Hegel ao seu tempo quando a epistemologia separava os conhecimentos da Natureza e os conhecimentos do Espírito. A unidade entre Natureza e Espírito é restabelecida através do conhecimento filosófico da Natureza, especialmente com o conhecimento do espírito subjetivo de estruturas lógicas na Natureza, o que significa a sua suprassunção da condição de Natureza empírica em Natureza significada e propriamente racional. Desta forma, a passagem da Ciência da Lógica para a Filosofia da Natureza está marcada pelo paradoxo da divisibilidade e da indivisibilidade, pois na posição da radical diferença, a Ideia lógica permanece indivisível. Não se trata de um movimento secundário, como 
se a Natureza fosse uma contingência exterior e secundária em relação à Ciência da Lógica, mas a divisibilidade torna-se indivisível ao integrar as diferenças mais radicais num único movimento sistemático. Conforme o texto hegeliano, a Ideia se entrega radicalmente à Filosofia da Natureza, porque neste movimento a Ciência da Lógica desaparece como pura lógica e puro pensamento, aliena-se radicalmente da diferença e a reintegra a ela. Se a Ideia se entrega à Filosofia da Natureza, isto significa sustentar que a Natureza é impregnada pela racionalidade que vem da primeira esfera do sistema, quando a Natureza se determina em sua própria lógica imanente.

O movimento de passagem da Ciência da Lógica para a Filosofia da Natureza também pode ser considerado pela perspectiva de uma Teologia especulativa. A proposição segundo a qual Deus permanece igual no seu determinar-se significa que a igualdade consigo mesmo somente é possibilitada no movimento de determinação e de diferenciação. Sob este ponto de vista, estruturas reais como a Natureza, a História e o Universo são estruturalmente constitutivos de Deus, na condição de estruturas imanentes e momentos racionais de seu autodesenvolvimento. Hegel supera a antiga Teologia cristã, na qual a incondicionalidade e absoluticidade de Deus são anteriores à criação do mundo, como se fossem meros efeitos rebaixados. Na formulação hegeliana, cada círculo particular é a Ideia total na determinidade daquela parte, em cuja lógica a Filosofia da Natureza é a totalidade divina na particularidade dessa esfera. De forma sintética, Hegel já antecipa o argumento de que a Filosofia da Natureza pode ser interpretada nas figurações lógicas de universalidade, particularidade e singularidade. A Filosofia da Natureza aparece como universalidade em razão de sua significação universal enquanto racionalidade da Natureza e, enquanto a inteligibilidade lógica, é a ela intrínseca. A Filosofia da Natureza aparece como particularidade enquanto círculo particular e determinação da Ideia, como momento do processo de autodesenvolvimento dela. Como singularidade, a Filosofia da Natureza é logicamente figurada como a totalidade do sistema, enquanto expressão da autodeterminação universal do sistema filosófico. Nesta condição de mediação fundamental, no interior 
dela estão contidas as outras esferas a partir das quais ela figura como círculo maior e propriamente universal. Hegel escreve:

Quanto a isto há que dizer: (a) a eternidade não é antes nem depois do tempo, não antes da criação do mundo nem quando ele se acaba; mas a eternidade é presente absoluto, o agora sem antes nem depois. O mundo é criado, vem a ser criado [está sendo criado] agora e eternamente foi criado; isto acontece na forma de conservação do mundo. Criar é a atividade da ideia absoluta; a ideia da natureza é, qual a ideia como tal, eterna. (b) Na pergunta se porventura o mundo, a natureza em sua finitude tem ou não um começo no tempo, tem-se diante da representação o mundo ou a natureza em geral, isto é, o universal; e o verdadeiramente universal é a ideia da qual já foi dito que ela é eterna. O finito, porém, é temporal, tem um antes e um depois; e quando se tem o finito diante de si se está no tempo. O finito tem um começo, mas nenhum [começo] absoluto. Seu tempo começa com ele e o tempo é só do finito. A filosofia é compreensão intemporal também do tempo e de todas as coisas em geral, segundo sua determinação eterna (HEGEL, 1995, §247, Zusatz).

A relação entre as duas primeiras esferas não é de justaposição entre eternidade e temporalidade, em conformidade com a concepção da maioria das religiões, mas a eternidade é temporalidade absoluta. A eternidade é definida por Hegel como presente absoluto sem passado e sem futuro, em razão de que no tempo presente convergem todos os tempos. $\mathrm{Na}$ configuração atual do mundo, reaparecem atualizados e reintegrados todos os mundos existentes no passado. Numa configuração sistemática do pensamento filosófico do presente serão reconduzidas todas as formas de pensamento desenvolvidas no passado. Hegel formula uma síntese entre a concepção tradicional de eternidade, como um universo estável e sem movimento, e a temporalidade, como referência ao mundo finito e mutável no movimento e na atividade absoluta. Nesta perspectiva, o filósofo também corrige o conceito clássico de criação, compreendido como um ser eterno e intemporal que cria, na posterioridade do tempo, 
a Natureza e o mundo. Segundo a formulação hegeliana, o mundo não foi criado pela ação de um ser absoluto preexistente, mas o mundo é uma eterna atividade de permanente criação e autoconstituição. $\mathrm{Na}$ relação entre a Ideia absoluta e a Filosofia da Natureza, ou entre Ideia eterna e Ideia de natureza, desenvolve-se uma atividade eterna e permanente intrínseca à Natureza e realiza o seu desenvolvimento. Não se trata, portanto, de uma relação linear entre a eternidade, a criação da Natureza e do mundo, como na tradição cristã, mas da coextensividade entre a reflexividade e interioridade da Ideia como atividade universal e a fundamentação da Filosofia da Natureza enquanto exposição imanente. Para Hegel, o presente é a eternidade do tempo sempre presente, pois o passado foi presente e é presente no presente, o presente é a eternidade absoluta de todos os tempos e o futuro será absolutamente presente. Trata-se de um movimento universal na intemporalidade absoluta, e de uma absoluticidade intemporal na temporalidade absoluta e presente.

\section{Da Filosofia da Natureza para a Filosofia do Espírito}

A passagem da Filosofia da Natureza para a Filosofia do Espírito caracteriza um patamar de autodesenvolvimento do sistema filosófico ao alcançar uma nova instância de efetivação global. Se a passagem da Ciência da Lógica para a Filosofia da Natureza estava marcada pela diferenciação e exteriorização da razão nas condições empíricas da Natureza, a passagem da Filosofia da Natureza para a Filosofia do Espírito caracteriza o caminho de retorno e de síntese integradora entre essas esferas. No último círculo do sistema filosófico, as duas esferas anteriores são conjugadas na síntese de uma única esfera, pois na Filosofia do Espírito a Ideia universal aparece como força de liberdade e a Filosofia da Natureza é suprassumida na segunda natureza da Sociedade, da Ética e da História. Nessa esfera de argumentação, as determinações conceituais da Ciência da Lógica e as determinações sistemáticas da Filosofia da Natureza estão parcialmente 
correlacionadas, de forma a caracterizar um sistema de autodeterminação do real, integradas na síntese do Espírito. Sobre isso, o filósofo escreve:

O espírito tem para nós a natureza por sua pressuposição, da qual ele é a verdade e, por isso, seu [princípio] absolutamente primeiro. Nessa verdade, a natureza desvaneceu, e o espírito se produziu como ideia que chegou ao seu ser-para-si, cujo objeto, assim como o sujeito, é o conceito. Essa identidade é a negatividade absoluta, porque o conceito tem na natureza sua objetividade externa consumada, porém essa sua extrusão é suprassumida, e o conceito tornou-se nela idêntico a si mesmo. Por isso o conceito só é idealidade enquanto é retornar da natureza (HEGEL, 1995, §381).

O Espírito é a verdade da Natureza. Numa primeira aproximação, a progressão dialética da Filosofia da Natureza na Filosofia do Espírito caracteriza uma lógica de ampliação, de universalização concreta, de evolução global do sistema no sentido quantitativo de ampliação e no sentido qualitativo de fundamentação de uma esfera mais elevada. Por este caminho, a verdadeira fundamentação não está na relação entre o sistematicamente primeiro e o sistematicamente segundo, tal como a Ciência da Lógica seria o fundamento da Filosofia da Natureza e esta da Filosofia do Espírito, mas na fundamentação retroativa que o Espírito estabelece em relação às esferas anteriores, dinamizada na perspectiva do movimento de autofundamentação. Na passagem da primeira para a segunda esfera, o sistema filosófico adquiriu o estatuto de constituição racional como ser-em-si, enquanto na plataforma sistemática do Espírito alcançou a qualidade racional de ser-para-si. O texto acima indica os diferentes momentos de fundamentação racional e de homologia com a Ciência da Lógica, pois o nível de desenvolvimento enquanto pura Lógica corresponde ao grau do ser, o nível de desenvolvimento enquanto Natureza corresponde ao grau racional da essência e o nível de desenvolvimento enquanto Espírito corresponde ao grau do conceito. Por isso, dentro do processo de desenvolvimento do sistema, o Espírito caracteriza o retorno a partir da exterioridade da Natureza na condição de subjetividade e obje- 
tividade conceitual. Na Filosofia do Espírito, não há mais uma subjetividade interior como Ideia de liberdade contraposta à exterioridade da natureza empírica, mas a objetividade do mundo e da história caracteriza uma efetividade espiritual. Agora não há mais relação de exterioridade entre a razão e a Natureza, mas a interioridade da razão e a exterioridade do real estão mutuamente compenetradas, permitindo o desenvolvimento sistemático e conceitual. Continuamos com o filósofo:

Como tínhamos dito, o espírito nega a exterioridade da natureza, assimila a si a natureza, e por isso a idealiza. Essa idealização tem uma figura unilateral no espírito finito que põe fora dele a natureza; aqui, à atividade de nosso querer, como também de nosso pensar, contrapõe-se um material exterior, que, indiferente perante a alteração que empreendemos com ele, experimenta de modo totalmente passivo a idealização de que assim participa. Mas no espírito que produz a história mundial ocorre outra relação. Pois já não se situa, de um lado, uma atividade exterior ao objeto, e de outro um objeto simplesmente passivo; mas a atividade espiritual dirige-se a um objeto ativo em si mesmo - a um objeto que se elaborou a si mesmo para [ser] aquilo que deve ser produzido por aquela atividade; de modo que na atividade o objeto está presente em um só e no mesmo conteúdo (HEGEL, 1995, §381, Zusatz).

$\mathrm{Na}$ Filosofia do Espírito, a Natureza é integrada ao Espírito e idealizada. Não se trata da simples identificação entre Natureza e Espírito, como no pensamento de Schelling, mas o Espírito é uma esfera qualitativamente mais elevada daquela e assume outra figuração lógica no contexto do sistema filosófico como um todo. Se no pensamento de Schelling, a natureza é estruturalmente auto-organizada a partir da força racional que habita nela, para Hegel, necessita de uma racionalidade anterior que ela interioriza na condição de significação racional. A Filosofia do Espírito não é composta por um lado ativo exteriormente aplicado ao outro lado supostamente passivo, mas caracteriza um objeto ativo em si mesmo, como uma autoatividade racional. Não se trata de uma dimensão subjetiva responsável pela atividade e uma dimensão objetiva movida por uma ação anterior, 
mas há uma única espacialidade e uma única atividade universal na qual se compenetram a atividade e a passividade de uma mesma realidade que se move a si mesma. Um dos principais círculos da Filosofia do Espírito é a História mundial não movida por uma Ideia absoluta anterior, mas o progredir da História é o caminho da autodeterminação do Espírito que produz a sua própria atividade e se produz por meio dela. Para Theunissen,

A filosofia hegeliana como um todo é uma Filosofia do Espírito, apresenta-se em sua totalidade, não apenas em uma disciplina, também como Filosofia da História. A tese conclusiva pode ser invertida: História é Espírito. Espírito e História são na mesma relação de coisas, no processo hegeliano da autodiferenciação e do retorno a si mesmo, a exteriorização no outro e a recondução a si mesmo (THEUNISSEN, 1970, p. 78).

A História mundial é, para Hegel, uma esfera da Filosofia do real na qual se identificam a atividade e a passividade. Ela é perpassada pela inteligibilidade da Ideia da liberdade que atravessa horizontalmente a trajetória da História e se determina em diferentes níveis de concreção da mesma racionalidade de liberdade. A Ideia de liberdade, com a sua força de concreção, desdobra-se na objetividade das civilizações, das épocas, das formas de organização política e de liberdade dos povos; estas, por sua vez, produzem, na efetividade histórica que lhes corresponde, a racionalidade da liberdade. Em outras palavras, trata-se da relação entre o Espírito do mundo e as obras históricas produzidas por aquele. O espírito do mundo caracteriza a autocompreensão global do homem no mundo como um pensamento sistematizado resultante da estrutura de intersubjetividade universal de todos os homens inter-relacionados; caracteriza, igualmente, a autoconsciência global de liberdade numa determinada civilização ou período histórico. A universalidade subjetiva da racionalidade da História efetiva-se na estrutura objetiva das épocas históricas, da organização política global, das obras históricas, das civilizações e das relações entre os Estados. As obras concretas da liberdade, por sua vez, produzem a 
autoconsciência universal de liberdade e a autocompreensão racional do homem sistematizada na forma de pensamento filosófico. Desta forma, a dinâmica da Filosofia do Espírito é uma ação constante de autodeterminação, negadora de estruturas históricas antigas e estruturadora de novas determinações históricas. Assim, segundo Theunissen, toda a filosofia hegeliana é Filosofia do Espírito, porque, para ela, confluem as outras partes da filosofia. Espírito e História formam uma unidade inseparável na circularidade integradora da subjetividade e da objetividade, da idealidade e da realidade. Espírito é História, em função da autodeterminação no mundo, nas civilizações, nas épocas, nas culturas e na sistemática de racionalidade filosófica que as sustenta, como uma efetivação do Espírito. A História é Espírito porque é a sua reflexividade fundamental, a sua inteligibilidade filosófica intrínseca e a sua autodeterminação racional. Para Hegel:

O espírito essente em si e para si não é o simples resultado da natureza, senão, na verdade, seu próprio resultado: a si mesmo produz, das pressuposições que para si mesmo faz - da ideia lógica e da natureza externa, e é a verdade tanto de uma como de outra; quer dizer, a verdadeira figura do espírito essente só em si, e do espírito essente só fora de si. A aparência de que o espírito seria mediatizado por um outro é suprassumida pelo espírito mesmo; pois ele tem a soberana ingratidão - por assim dizer - de suprassumir aquilo pelo qual parece mediatizado, de mediatizá-lo, de rebaixá-lo para algo que só subsiste por ele; e de se fazer, dessa maneira, perfeitamente autônomo (HEGEL, 1995, §381, Zusatz).

A Filosofia do Espírito não é um simples resultado da exposição sistemática configurada como síntese entre a Ciência da Lógica e a Filosofia da Natureza, conforme exposto anteriormente, mas ultrapassa a conjugação sintética entre os dois círculos anteriores e produz a sua própria estrutura sistemática. Aqui aparece a verdadeira fundamentação, pois o Espírito configura-se como o círculo de maior universalidade extensiva e intensiva e retorna à Natureza e à Lógica como determinações suas. A Filosofia do Espírito é a verdade, tanto da Ciência da Lógica, quanto da Filosofia 
da Natureza, pois sem o Espírito aquela permaneceria como uma vazia e formal racionalidade, enquanto a outra permaneceria na condição de natureza empírica. Suprassumida na universalidade concreta da Filosofia do Espírito, a pura racionalidade da Ciência da Lógica transpõe-se na racionalidade articuladora e dinamizadora do sistema do Espírito, portanto numa função diferente daquela puramente transcendental; enquanto a Filosofia da Natureza é suprassumida na esfera do Espírito na realidade da sociabilidade e da História, na condição de segunda Natureza. Do desenvolvimento sistemático que começa pela primeira esfera, cujo processo é mediatizado pela segunda, até a Filosofia do Espírito acontece em um movimento de ascensão qualitativo intrinsecamente conduzido na progressão do autodesenvolvimento do próprio sistema realizado na sistemática de relações interesféricas. Nesse movimento de progressão interesférico, a configuração do sistema caracteriza, primeiramente, uma horizontalidade de exposição de esferas parcialmente integradas pelas relações e parcialmente diferenciadas pela especificidade de suas configurações. A exposição sistemática também caracteriza um sentido de verticalidade, porque cada esfera comporta um grau de efetivação da Ideia universal que atravessa o sistema em todos os sentidos. Entre a Ciência da Lógica e a Filosofia do Espírito são vários níveis de fundamentação sistematicamente organizados, conforme exposição aqui empreendida. Outra forma de representação do processo de autoconstrução sistemático é a imagem da circularidade, primeiramente configurada em cada parte como círculo específico, passando para a Filosofia do Espírito configurada como círculo mais abrangente que integra os outros círculos como momentos estruturantes. O círculo dos círculos da Filosofia do Espírito, na condição de movimento de fundamentação retroativo, é mais amplo em universalidade concreta, em reflexividade e em sistematicidade. Nesse sentido, na configuração sistemática até aqui alcançada, há duas esferas particulares contrapostas entre si na condição de racionalidade e de exterioridade material, a Ciência da Lógica e Filosofia da Natureza; enquanto a Filosofia do Espírito representa a universalidade sintética e concreta. 
A lógica do Espírito não pode ser compreendida como manifestação, assim como na Revelação cristã Deus se manifesta na Natureza e na História. Hegel compreende o Espírito como automanifestação, na coincidência da essência com o movimento de exteriorização. A esfera do Espírito é um universo no qual se identificam a forma e o conteúdo, num processo dialético em que a forma da inteligibilidade da razão, permanentemente, se manifesta, e a "exterioridade" do conteúdo põe a própria razão. $\mathrm{Na}$ Filosofia do Espírito, a exterioridade do conteúdo não caracteriza uma manifestação superficial e não representa um rebaixamento empírico em relação à excelência da sublime razão absoluta, mas a estrutura do conteúdo contém o mesmo grau de verdade e de racionalidade que a própria forma. Na esfera do Espírito desaparece a assimetria ainda existente da relação entre a Ciência da Lógica e a Filosofia da Natureza, pois essa não corresponde ao seu conceito, elevando o sistema filosófico à autodeterminação da razão. A identidade dialética entre sistema e liberdade, entre logicidade e eticidade, na pulsão do desenvolvimento sistemático no qual se equivalem a razão teórica e a razão prática são expostos num constante movimento de superação e de construção. O processo de exposição dialético não constitui um simples meio para alcançar um resultado perfeito, tal como poderia ser a manifestação fenomenológica do Espírito, mas caracteriza um eterno movimento de desenvolvimento. Disso resulta, por exemplo, a compreensão da filosofia hegeliana como um sistema de liberdade. ${ }^{2}$ Richard Kroner escreve:

A Filosofia do Espírito é para si mesma o vir-a-ser da Filosofia, quem para si mesma é vir-a-ser do Espírito. Espírito e Filosofia são concretamente idênticos; a Filosofia é em si mesma o saber do vir-a-ser,

\footnotetext{
2 Dentre as obras mais representativas podemos citar: ANGEHRN, E. Freiheit und System bei Hegel. Berlim: Walter de Gruyter, 1977; JARCZYK, G. Système et Liberté dans la Logique de Hegel. Paris: Aubier-Montaigne, 1980; LAKEBRINK, Bernhard. Die Europäische Idee der Freiheit. Hegels Logik und die Tradition der Selbstbestimmung. Netherlands: Leiden E. J. Brill, 1968; THEUNISSEN, Michael. Hegels Lehre vom absoluten Geist als theologisch-politischer Traktat. Berlin: Walter de Gruyter, 1970.
} 
que é em si o vir a ser do Espírito, que em si mesmo é Espírito pensante como Ideia pensante da unidade do Logos, da Natureza e do Espírito, de Lógica, Natureza e Filosofia do Espírito. O Espírito se torna Filosofia, porque ele pensa em si mesmo a Filosofia; este vir-a-ser é a atividade do Espírito, enquanto ainda não é filosófico, ainda não pensante o vir-a-ser do pensante, no conceito de Filosofia em si mesmo Espírito pensante. Ou: o vir-a-ser do Espírito é ao mesmo tempo lógico e espiritual, as determinações conceituais do Espírito são, logo, efetivações do Espírito; este somente é possível porque o Espírito para si ou se conceituar como Espírito pensante (assim a Natureza é para si Espírito, o ser para si conceito), porque o pensar do Espírito é o espiritual, apenas por si dialeticamente captável (KRONER, 1961, v. 2, p. 517-518, trad. minha).

No sistema filosófico hegeliano, Filosofia e Espírito se fundem num único movimento de exposição. As três configurações do Espírito - subjetivo, objetivo e absoluto - alcançam a sua determinação mais elevada na Filosofia. A atividade mais nobre e aprofundada do Espírito subjetivo é o exercício do pensar filosófico, por meio do qual penetra a interioridade da consciência, afasta-se da objetividade imediata do mundo para penetrar em sua figuração racional mais aprofundada. $O$ espírito objetivo, estruturado no desdobramento da liberdade no sistema de sociabilidade e articulado no movimento dialético da subjetividade e da intersubjetividade, da multiculturalidade e da interculturalidade, e desemboca na filosofia como a determinação cultural mais elevada e mais qualificada. No universo do Espírito, a Filosofia aparece como o conhecimento mais universal e mais sistemático da cultura resultante da autoconsciência da sociedade e da humanidade num determinado período histórico, e como sistematização racional deste conhecimento no discurso do código da razão filosófica. Diante da intersubjetividade e interculturalidade das relações sociais, a Filosofia é a expressão mais universal e mais elaborada do autoconhecimento do povo. Com essas considerações, a Filosofia do Espírito é o resultado do vir-a-ser da Filosofia que aparece desenvolvida e efetivada no sistema do Espírito; enquanto a mesma esfera representa o vir-a-ser do Espírito na 
sua própria autodeterminação e consciência filosófica. Como Filosofia do Espírito, a Filosofia evolui eticamente para o sistema de eticidade universal e epistemologicamente para o sistema filosófico; enquanto o Espírito evolui para a autocompreensão de si mesmo no saber filosófico.

\section{Da Filosofia do Espírito para o Espírito Absoluto³}

A passagem da Filosofia do Espírito para a esfera do Espírito absoluto é fundamental para uma compreensão conjunta do sistema filosófico hegeliano. Trata-se, em outras palavras, da passagem da Filosofia da História universal para a História da Filosofia, da objetividade do real para a absoluticidade. Não se trata, evidentemente, do retorno a uma razão teórica sobreposta ao nosso mundo real, mas a noção hegeliana de Espírito absoluto estabelece uma reconfiguração global do sistema filosófico. Nessa esfera, não se trata mais da sequência horizontal da redação da Enciclopédia das Ciências Filosóficas em Ciência da Lógica, Filosofia da Natureza e Filosofia do Espírito, mas constituem-se outras formas de mediação e outras possibilidades de sistematização do modelo filosófico hegeliano. A esfera que se constitui não é simplesmente exterior e posterior aos círculos anteriores, não é o retorno ao tranquilo mundo inteligível, mas caracteriza o círculo universal, o círculo dos círculos que reintegra os outros. Trata-se de uma síntese entre progressão e regressão, resultado do caminho e caminho para o resultado, na síntese do movimento absoluto e eterno. Bernhard Lakebrink caracteriza esta esfera:

\footnotetext{
3 Sobre esse nível de constituição da filosofia hegeliana, as principais obras são ANGEHRN, Emil. Freiheit und System bei Hegel. Berlin: Walter de Gruyter, 1977; THEUNISSEN, Michael. Hegels Lehre vom absoluten Geist als theologisch-politischer Traktat. Berlin: Walter de Gruyter, 1970. O que há de comum entre os dois filósofos é a exposição horizontal do sistema hegeliano que compreende a trajetória metódica desde a Ciência da Lógica até o Espírito Absoluto, quando são expostas as mediações sistemáticas. Michael Theunissen expõe os silogismos constantes nos últimos parágrafos da Enciclopédia das Ciências Filosóficas (p. 574-577), enquanto Emil Angehrn enfoca o sistema como uma teoria do Espírito Absoluto, uma Filosofia da história e uma teoria da Filosofia.
} 
O Logos não está aqui apenas como Ideia, como na Lógica, não mais apenas saber absoluto como na Fenomenologia, mas como Espírito absoluto. O Logos é Espírito absoluto, enquanto ele não apenas brota das determinações do pensamento (Lógica), não apenas das formas da consciência (Fenomenologia), mas das realidades da Natureza e da História, Espírito subjetivo e objetivo, da arte e da religião a si mesmo se reconduz. Esta recondução do Logos a partir das efetividades do mundo e do espírito é o Espírito absoluto na forma do desenvolvimento da filosofia, como Logos pensante tem em si mesmo a forma do desenvolvimento da filosofia. Também aqui se mostra dentro de si a autodeterminação circular: no final da Lógica o Logos se exterioriza como Ideia absoluta, uma vez imanente, no interior da Lógica, onde ele se renova como pensamentos do ser. Logo, o Logos se exterioriza no final da Lógica como transiente, no qual se determina como criador do mundo. A partir desta exterioridade, a Ideia absoluta ou o Logos reconduz a si mesmo e se sabe a si mesmo no final da Enciclopédia como Espírito absoluto. $\mathrm{O}$ Espírito absoluto é resultado (fim) do espírito finito e seu mundo (LAKEBRINK, 1968, p. 24-25, tradução nossa) ${ }^{4}$.

\section{O Logos não se restringe à Ideia absoluta da Lógica aplicada às determi-} nações do real, mas brota de todas as esferas do sistema e é constituído como círculo universal e absoluto. Conforme parcialmente demonstrado acima, o Espírito absoluto é resultado sistêmico do caminho de universalização

\footnotetext{
${ }_{4}$ Der Logos ist hier nicht nur als Idee, wie in die Logik, nicht mehr nur als absolutes Wissen wie in der Phänomenologie, sondern als absoluter Geist. Der Logos ist absoluter Geist, sofern er nicht nicht nur aus Gedankenbestimmungen (Logik), nicht nur aus Bewusstseinsformen (Phänomenologie), sondern aus den Realitäten von Natur und Geschichte, subjektivem und objektivem Geist, aus Kunst und Religion zu sich zurückkehrt. Diese Rückkehr des Logos aus den Wirklichkeiten von Welt und Geist ist nun der absolute Geist in der Entwiklungsform von Philosophie, wärend der sich denkende Logos die Entwiklungsform der Logik hat. Auch hier zeigt jenes in sich zirkelnde Selbstbestimmungen: am Ende der Logik entäussert sich der Logos as absolute Idee, einmal immanent, innerhalb der Logik, wo er sich erneut als den Gedanken von Sein denkt. Zugleich entässert sich der Logos am Ende der Logik aber auch transiente, indem er sich zur Schöpfung einer Welt entschliesst. Aus dieser Äusserlichkeit kehrt die absolute Idee oder der Logos zu sich selbst zurück und erweist sich so am Ende der Enzyklopädie als absoluter Geist. Der absolute Geist ist mithin Resultat (Ende) von endlichem Geist und seiner Welt (LAKEBRINK, 1977, p. 24-25).
} 
concreto que parte da Lógica, se complexifica na Natureza e no Espírito, como uma lógica de ampliação e de exteriorização, e é reconduzido à reflexividade do Espírito quando é completado o círculo do Espírito absoluto. Nessa estruturação cíclica do universo do Espírito, configura-se como início, como meio e como fim. Na condição de começo, o Espírito absoluto autodetermina-se nas esferas da Lógica, da Natureza e do Espírito resultantes da lógica do autodesenvolvimento imanente e de progressiva expansão dessas estruturas. Como fim, é determinado como resultado da exposição metódica do sistema no qual todas as determinações se universalizam e alcançam a síntese. Como meio, o Espírito absoluto estabelece elos de ligação entre as esferas, perpassa o sistema por dentro como racionalidade fundamental e, por esta razão, expressa a relacionalidade fundamental na qual as esferas se constituem e se integram. Como mediação, todas as esferas são reconduzidas à interioridade do Espírito na mútua implicação da relacionalidade imanente do sistema, e todas as esferas constituem a interioridade do Espírito absoluto quando se determina como círculo absolutamente universal. Nessa esfera mais ampla, a síntese universal do círculo dos círculos representa, enquanto interioridade do sistema, um desdobramento circular das esferas que se tornam mais complexas e amplas, enquanto exterioridade universal as estruturas se constituem em seu interior. Com Hegel completamos este raciocínio:

Cada uma das partes da filosofia é um Todo filosófico, um círculo que se fecha sobre si mesmo; mas a ideia filosófica está ali em uma particular determinidade ou elemento. O círculo singular, por ser em si totalidade, rompe também a barreira de seu elemento e funda uma esfera ulterior. Por conseguinte, o todo se apresenta como um círculo de círculos, cada um dos quais é um momento necessário, de modo que o sistema de seus elementos próprios constitui a ideia completa, que igualmente aparece em cada elemento singular (HEGEL, 1995, §15). 
O parágrafo da citação acima integra um conjunto de textos densos da introdução à Enciclopédia das Ciências Filosóficas. Neste texto, Hegel condensa o movimento, o método e a estrutura como um círculo de totalidades que, reciprocamente, se mediatizam e constituem, nesta circularidade e intercircularidade, o movimento universal do círculo dos círculos. Numa primeira aproximação, cada uma das esferas fecha o seu próprio círculo de exposição e desenvolvimento categorial que coincide com a abertura à outra esfera. Nesta lógica, cada uma das partes da filosofia é uma totalidade filosófica, pois, ao perfazer o seu próprio círculo, integra o círculo das outras partes da filosofia. Nesta circularidade, cada esfera determina o ciclo das outras esferas, é determinada pelas outras e se determinam reciprocamente no processo universal de heterodeterminação e autodeterminação. Cada uma das esferas é uma totalidade filosófica porque o sistema filosófico alcança em cada qual uma totalidade determinada, em cujo raciocínio cada uma pode ser determinada como a totalidade sintética das outras. Neste sentido, na perspectiva do Espírito absoluto, o sistema filosófico é sistematicamente dinamizado numa sequência estrutural de círculos em universalização no círculo dos círculos, resultante do movimento lógico de interrelação estabelecido entre os círculos. Conforme texto hegeliano, o círculo dos círculos é o próprio movimento de circularidade universal resultante da intercircularidade recíproca entre as totalidades e expressão da relacionalidade absoluta do sistema estruturado em relações intraesféricas e interesféricas. Dessa maneira, parece que o círculo dos círculos do Espírito absoluto caracteriza uma quarta esfera, não exterior às outras, mas uma reconfiguração e reestruturação completa do conjunto do sistema. Como veremos, configura-se, nessa esfera, a autoatividade e a relacionalidade universal absolutas, resultantes das múltiplas relações interesféricas integradas na autorrelação universal. Essas relações caracterizam o duplo movimento de totalização dos círculos particulares no círculo absoluto e do retorno deste para as determinações particulares. A complexidade do parágrafo quinze supera a lógica da exposição linear 
e horizontal das esferas, como é a exposição da Enciclopédia das Ciências Filosóficas, mas evolui para a tríplice circularidade, na medida em que cada parte fecha um círculo, a interpenetração circular constitui uma interação substancial do sistema e a circularidade global, que caracteriza o círculo dos círculos. Seguimos com Hegel:

O sentido objetivo das figuras do silogismo é, em geral, que todo o racional se mostra como um tríplice silogismo; e isso de tal modo que cada um de seus termos tanto ocupa a posição de um extremo como também a do meio-termo mediatizante. $E$, em especial, o caso com os três termos da ciência filosófica, isto é, a ideia lógica, a natureza e o espírito. Aqui é primeiro a natureza o termo mediador, que conclui juntamente (os outros). A natureza, essa totalidade imediata, se desdobra nos dois extremos da ideia lógica e do espírito. Mas o espírito só é espírito ao ser mediatizado pela natureza. Em segundo lugar, é igualmente o espírito que nós conhecemos como o individual, o ativo, [que é] o meio-termo; e a natureza e a ideia lógica são os extremos. E o espírito que na natureza conhece a ideia lógica, e assim a eleva à sua essência. Igualmente, em terceiro lugar, a própria ideia lógica é o meio-termo; é ela a substância absoluta do espírito, como da natureza: o universal que-tudo-penetra. São esses os termos do silogismo absoluto (HEGEL, 1995, §187, Zusatz).

Um dos pontos estruturantes da esfera do Espírito absoluto é o conjunto dos silogismos expostos por Hegel no final da Enciclopédia das Ciências Filosóficas (\$574-577), figurados em várias formas de mediação. Para Hösle: "Segundo Theunissen, a primeira conclusão corresponde à Enciclopédia em seu conjunto; a segunda, à Fenomenologia do espírito; a terceira, enfim, à Filosofia da religião, a qual seria lida na perspectiva da Enciclopédia" (HÖSLE, 2007, p. 170-171). No parágrafo da citação acima, Hegel expõe sinteticamente o conteúdo e a estrutura dos silogismos esboçados no final da Enciclopédia das Ciências Filosóficas, com destaque na mediação objetiva da Filosofia da Natureza, na mediação subjetiva da Fenomenologia do Espírito e na mediação sistemática da Filosofia da 
Religião. Não é possível analisar, neste artigo, todas as figurações de silogismos indicados no texto denso do adendo, mas interessa, tão somente, abordar uma dimensão desta formulação hegeliana. Na completude do desenvolvimento silogístico, as esferas da Ciência da Lógica, da Filosofia da Natureza e da Filosofia do Espírito constituem, todas elas, o começo, a mediação e o fim do silogismo. Cada uma destas esferas, em determinado momento, aparece como a totalidade do sistema filosófico na condição da determinidade desta esfera. O movimento lógico de mediação universal transforma cada uma destas esferas na função lógica de universalidade, particularidade e singularidade. A mediação sistemática, segundo a qual cada esfera assume todas as posições do silogismo, evidencia o movimento universal da esfera do Espírito absoluto. Para Kroner:

\begin{abstract}
A Lógica é toda a filosofia como momento de si mesma; e toda a filosofia é estendida ao sistema, Lógica completada. Só quem visualiza a relação dialética de Lógica e Sistema, entende, em que sentido o Sistema é governado pela Lógica. É por ela governado porque também a Lógica é governada pelo Sistema. A filosofia é Lógica porque é pensar; mas não é apenas lógica, senão cheia de conteúdo, pensamento ontológico, e isto já como Lógica. A relação dialética de Lógica e Sistema, e também aquela de Logos e Espírito é mesmo uma relação lógica, como toda a relação, que sempre pode ser pensada; isto é, logo, não apenas uma relação lógica, pois o Espírito ultrapassa o Logos quando se pensa e se põe em relação com ele, se concebe como Logos e se contrapõe ao Logos, ele ultrapassa a Lógica (KRONER, 1961, v. 2, p. 509).
\end{abstract}

Na formulação de Kroner, a Lógica hegeliana não se restringe à primeira esfera do sistema filosófico, seguida de círculos não lógicos. A Lógica não apenas é estruturada pelo desenvolvimento dialético do pensamento na trajetória racional, lógica e epistemológica que vai da Doutrina do Ser até a Doutrina do Conceito, mas a Lógica compreende todo o percurso sistemático e interesférico ampliado na Filosofia da Natureza e na Filosofia do Espírito. Desta forma, a relação entre Lógica e Sistema compreende o 
próprio processo de ampliação da primeira para a segunda, coordenando os principais processos lógicos e estruturas de interconexão entre as esferas. Por esta via, há uma lógica da Ciência da Lógica, uma lógica da Filosofia da Natureza, uma lógica da Filosofia do Espírito e uma lógica do sistema filosófico em sua totalidade, como a universalidade e totalidade do lógico. Esta perspectiva de interpretação define a Ciência da Lógica como a universalidade filosófica que se determina na forma de uma metalógica da Enciclopédia das Ciências Filosóficas. De forma simples, a Ciência da Lógica se estende para os outros círculos do sistema e as contém como determinações suas. O caminho de construção e de articulação do sistema pode ser invertido segundo o qual o próprio sistema e a esfera da Filosofia do Espírito ultrapassam a Lógica e a estabelecem como uma determinação imanente. Neste formato exposição, a Ciência da Lógica não é mais o primeiro círculo do sistema, mas é deslocado para a posição de mediação em cuja estrutura racional as esferas da Natureza e do Espírito são imanentes à própria Lógica, no formato de Espírito, Lógica e Natureza. Nesta configuração, o sistema da Enciclopédia das Ciências Filosóficas se determina racionalmente como uma totalidade em movimento e num círculo de interrelações transversais entre as esferas particulares. Na perspectiva da Filosofia do Espírito, nessa configuração silogística, a Lógica passa para a função de determinação imanente e como momento do sistema quando o Espírito se autodetermina racionalmente, como um sistema de concretude e totalidade em automovimento.

A consolidação desse silogismo abre o círculo da figuração Ciência da Lógica, Filosofia da Natureza e Filosofia do Espírito. Essa mediação não caracteriza uma repetição do primeiro silogismo no qual os termos ainda não são mediatizados, mas os extremos são expostos na perspectiva do termo médio. Essa configuração apresenta uma significativa novidade, porque a Ciência da Lógica não é apresentada como o fundamento primeiro do sistema filosófico, mas o sistema da Filosofia da Natureza contém em seu interior uma Ciência da Lógica como resultado da formalização racional das estruturas e dos movimentos da Natureza. Como 
uma Natureza qualificada e mediadora das outras esferas, considera-se a Ciência da Lógica na perspectiva da Filosofia da Natureza, especialmente na lógica do desdobramento de seus círculos. Um exemplo desse desenvolvimento é a parte da orgânica, estruturada nos capítulos da inorgânica, da orgânica e do gênero, segundo a dialética conceitual da universalidade, da particularidade e da singularidade. Em outras palavras, a Natureza alcançou um nível de desenvolvimento racional na qualidade de uma subjetividade da Natureza que proporciona o movimento de sua autoestruturação. Por outro lado, a Filosofia do Espírito é configurada na perspectiva da Filosofia da Natureza, na medida em que o Espírito é imanente à Natureza e ao universo. Nesse prisma, a esfera da Natureza configura-se como a totalidade maior, especialmente na Cosmologia contemporânea, na qual o Espírito é conhecido como o Espírito do Universo, como a atividade intrínseca de desenvolvimento das fases, das estruturas e dos movimentos de evolução. Segundo configuração desse momento silogístico, na nossa interpretação, a Filosofia da Natureza hegeliana pode ser traduzida para algumas posturas contemporâneas, destacadamente no Evolucionismo, de Teilhard de Chardin, estruturado dialeticamente nos processos da Cosmogênese, da Geogênese, da Biogênese e da Noogênese. Nessa postura, o movimento do Espírito brota de dentro do Universo na coextensividade dos processos e sistemas físicos e espirituais. A sequência pode ser introduzida com Michael Theunissen:

A tese sistemática que pretendemos expor, diz: A filosofia hegeliana do Espírito absoluto repousa num sistema que é coextensivamente concebido como uma Filosofia da História e uma Filosofia da Religião. Filosofia da História não é uma disciplina particular, mas o sistema hegeliano, sobretudo e como totalidade, num mesmo grau de universalidade uma Filosofia da Religião. Apenas no fundamento de tal coincidência do pensamento histórico e religioso pode a Teoria do Espírito absoluto ser um tratado político-teológico (THEUNISSEN, 1970, p. 60-61). 
A última configuração do silogismo absoluto é o formado pela Filosofia da Natureza, Filosofia do Espírito e Ciência da Lógica. Nessa figuração, a Filosofia do Espírito, nas configurações de espírito subjetivo, espírito objetivo e Espírito absoluto, realiza a mediação entre a Natureza e a Lógica. Aqui começamos a abordagem pelo viés do espírito objetivo, precisamente pela mediação da Filosofia da História universal. Segundo Theunissen, ela não caracteriza apenas uma parte do sistema filosófico hegeliano, mas todo o sistema pode ser compreendido como uma Filosofia da História. Como mediação fundamental, todo o sistema filosófico é resultado de um processo de desenvolvimento histórico, como uma autocompreensão e autossistematização da História na filosofia hegeliana. Nessa perspectiva, a História ultrapassa a caracterização de uma exterioridade imediata e fenomênica, mas tudo tem uma história, passa pela História universal e é compreendido na perspectiva dela. Na consubstancialidade entre Filosofia da História e Filosofia da Religião, uma teoria filosófica do Espírito absoluto é o resultado da compreensão histórica do Absoluto e epistemologicamente organizada em forma de sistema filosófico, especialmente no modelo hegeliano. Nesse círculo interdisciplinar integrador da História universal e do Espírito absoluto, não é mais o Absoluto que se exterioriza na História, mas a integração das duas esferas caracteriza o autodesenvolvimento histórico do Absoluto, num movimento dialético que integra todas as esferas do real e do pensamento, como uma universalização do particular e como uma particularização do universal. Desta forma, o processo de desenvolvimento, o sistema de interações multilaterais das esferas do pensamento e do real, na sistemática de evolução universal, caracteriza uma forma da historicidade absoluta. Na condição de mediação entre Ciência da Lógica e Filosofia da Natureza, as duas esferas devem ser interpretadas em chave histórica. Nessa abordagem, a Lógica ultrapassa a dimensão de sistema de pensamento puro para ser compreendida como racionalidade da História, somente possível de ser sistematizada na filosofia do Idealismo alemão. A Filosofia da Natureza também deve ser lida na perspectiva histórica, porque Hegel realiza, nesse círculo do sistema, 
uma sistematização crítica da compreensão da Natureza de seu tempo ao referenciar esta crítica a partir da ruptura com a concepção newtoniana e kantiana de Natureza. Nessa coextensividade entre Filosofia e História, a Filosofia nasce da História, se enrola com a História, se manifesta na e como História e é interiorizada pela História. Hegel escreve:

Os diversos graus da ideia lógica encontramos na história da filosofia, na figura de sistemas filosóficos que fizeram aparição um após o outro. Cada um deles tem por sua base uma definição particular do absoluto. Ora, assim como o desenvolvimento da ideia lógica se mostra como um progresso do abstrato para o concreto, assim também na história da filosofia os sistemas mais antigos são os mais abstratos e, por isso, os mais pobres. Aliás, a relação dos sistemas filosóficos do início para com os que vieram mais tarde é em geral a mesma que a relação dos graus anteriores da ideia lógica para com os posteriores; e, na verdade, de modo que os posteriores contenham em si os anteriores como suprassumidos. É este o verdadeiro significado da refutação que ocorre na história da filosofia, e é tantas vezes mal-entendida de um sistema filosófico por outro, e, mais precisamente, do sistema anterior pelo posterior (HEGEL, 1995, §86, Zusatz).

A mesma configuração silogística pode ser lida pelo viés da mediação da História da Filosofia, especialmente na perspectiva da relação entre o sistema da Enciclopédia das Ciências Filosóficas com o conjunto da História da Filosofia. Como veremos abaixo, a História da Filosofia compreende o movimento universal de construção da filosofia, esboçado num processo de constituição de sistemas filosóficos e modelos de racionalidade sistematicamente articulados pelo caminho de autodeterminação do pensamento filosófico. Por esse método, o modelo filosófico hegeliano é resultado desse imenso e amplo processo de desenvolvimento, pois a estrutura do sistema filosófico incorpora momentos estruturantes da História da Filosofia. Nessa primeira posição da filosofia hegeliana, ela resulta do movimento de universalização e de complexificação da História da Filosofia, atravessando especialmente as principais formulações da 
tradição filosófica neoplatônica, como Platão, Agostinho, Nicolau de Cusa, Espinosa, Fichte e Schelling. Essa trajetória pode ser estabelecida por um caminho filosófico cronologicamente mais curto, mas não menos complexo, dos sistemas de Espinosa, Kant, Fichte e Schelling, na sistemática global do Idealismo subjetivo e objetivo. A mediação da História da Filosofia compreende outra lógica estabelecida pelo caminho retroativo da filosofia, por meio do qual o sistema hegeliano significa um olhar filosófico retroativo, e todos os sistemas filosóficos são restabelecidos e reintegrados à atualidade sistemática do pensamento filosófico, quando a absoluta atualidade da filosofia se inova permanentemente. Entre os movimentos de progressão e regressão, a mediação da História da Filosofia aparece como universalidade absoluta, como movimento universal absoluto, em cuja interioridade os múltiplos sistemas filosóficos figuram como determinações imanentes. Esse sistema caracteriza uma totalidade em autodesenvolvimento, articulada no movimento dialético de exposição, num movimento universal que estabelece novos fundamentos e se estende em novos círculos de racionalidade filosófica. Nesse sentido, como mediação, a História da Filosofia faz compreender a Filosofia da Natureza nos diferentes momentos históricos, evidenciando questões importantes do período histórico de Hegel, estendíveis para a atualidade. Nesse esquema, a Ciência da Lógica pode ser lida como a racionalidade intrínseca da História da Filosofia, marcando os seus principais momentos e movimentos de desenvolvimento. Hegel indica o caráter abstrativo dos primórdios da filosofia e percebe o enriquecimento sucessivo que começa pelas formulações mais abstratas e evolui para sistemas mais amplos e complexos, tais como de Espinosa, Fichte e Hegel. Por esse caminho, a Ciência da Lógica articula o processo de desenvolvimento da História da Filosofia, enquanto a mesma Ciência da Lógica é resultado da evolução da História da Filosofia que nela encontra a sua expressão mais elevada.

Também significamos o mesmo silogismo Natureza, Espírito e Lógica pelo viés do Espírito absoluto. A filosofia sistemática hegeliana desemboca nesse formato de mediação. A mediação da História da Filosofia 
conduziu para a Filosofia da Filosofia, a uma espécie de Metafilosofia caracterizadora da autocompreensão e autossistematização do próprio pensamento filosófico. Na mediação do Espírito absoluto é configurada a dimensão eminentemente espiritual, na universalidade concreta do real em sua autodeterminação racional. Como mediação universal, o Espírito absoluto mediatiza e interliga sistematicamente todas as determinações do real, como o círculo universal absoluto, no interior do qual todas as determinações do real são constituídas e mediadas. Trata-se do autoconhecimento universal do Absoluto, do conhecimento humano do Absoluto e do autoconhecimento filosófico do homem no Absoluto. Nessa esfera não se dá um processo de exteriorização do Absoluto, assim como pode ser formulado em outros silogismos, mas um autodesenvolvimento imanente, no qual as determinações da Lógica, da Natureza, da História e do Universo são círculos que estabelecem a estrutura interna. Dessa forma, a autodeterminação do Absoluto se ramifica e se particulariza nessas diferenças internas mediante as quais não pode ser pensado como abstrato, mas o Espírito é absolutamente concreto. Por outro lado, esses círculos particulares, no movimento de interrelacionalidade fundamental, constituem a universalidade e totalidade do Espírito absoluto. Da combinação dos dois movimentos que atravessam multilateralmente o sistema inteiro e mediatizam os círculos particulares, resulta uma estrutura dinâmica de macrorrelacionalidade, totalizando um sistema e um círculo de Relação absoluta. Em outras palavras, na sua dimensão objetiva, o Espírito absoluto caracteriza uma tensão segundo a qual a interação fundamental entre todas as esferas produz a universalidade absoluta, e esta, por sua vez, é traduzida nas esferas diferenciadas e em suas interações multilaterais. Não se restringe à intersubjetividade que interconecta todos os sujeitos individuais num sistema universal, mas um sistema espiritual no qual as estruturas se universalizam nas outras, e todas as outras estruturas particularizam-se em um ou outro círculo particular. Em outras palavras, os sistemas particulares são transversalmente atravessados por movimentos e ondas relacionais constitutivas de uma espécie de ontologia da 
Relação absoluta, na qual o sistema relacional é mais forte que os círculos particulares. Sobre a Filosofia da Religião:

Deus é Espírito, que nós denominamos como a triunidade divina. Puro conteúdo especulativo, este é o mistério divino; Deus é Espírito, a absoluta atividade, ato puro, isto é subjetividade, infinita personalidade, infinita diferenciação de si mesmo a partir de si mesmo; mas esta diferenciação, a objetivação de si mesmo, a objetiva divindade de si - é no eterno conceito de universalidade preservado como absoluta subjetividade; assim está posto na sua infinita diferenciação, não para ser para si, intransparente, incompenetrável, finitizou-se, mas é logo em sua diferença nesta unidade imediata que permanece em si mesmo como o total conceito divino - Filho e Deus; esta absoluta unidade consigo mesmo na sua diferença idêntica consigo - o eterno amor (HEGEL, 1995, p. 16).

Ao longo da exposição da Enciclopédia das Ciências Filosóficas, Hegel formula diferentes níveis de determinação do Absoluto, tais como o ser de Parmênides e de Heráclito, a substância spinozista, o conceito e o objeto absoluto, no capítulo da Doutrina do Conceito que trata da objetividade. Talvez, a mais ampla e complexa formulação hegeliana sobre essa temática é a simples proposição segundo a qual Deus é Espírito, como triunidade divina. O Espírito aparece como síntese entre unidade e diversidade, entre unificação e diferenciação, entre absoluticidade e relatividade, entre absoluta subjetividade e absoluta intersubjetividade. Na triunidade divina, a unidade divina na diversidade das pessoas e a triadicidade na unidade caracteriza a proposição segundo a qual Deus é Espírito. Em Deus e no Universo, a unidade entre a unidade e a diferença se dá na interrelação das Pessoas divinas e das estruturas que compõem o real. A referência de Hegel a Deus como atividade absoluta caracteriza o movimento universal semovente, a autodeterminação universal totalizadora do Absoluto, na qual se identifica a dualidade tradicional entre criador e criatura. $O$ Absoluto é criador porque na sua incondicionalidade absoluta tudo é 
incluído e tudo é determinado, é criatura porque a sua ação não resulta em determinação exterior, mas caracteriza o movimento de autodeterminação universal. Nesse sentido, todas as forças combinadas do mundo e do universo e todas as relações entre todos e entre as Pessoas divinas constituem a autorrelação e a autodeterminação universais. Deus é ato puro porque tudo nele se atualiza de forma permanente, no movimento de desenvolvimento em cujo dinamismo tudo se atualiza na totalização universal. A tensão entre a absoluta subjetividade e a infinita diferenciação é a referência para a estruturação de um sistema subsistente em si mesmo, ao mesmo tempo uno e múltiplo, em que a diferença infinita é a expressão da autodiferenciação da subjetividade absoluta, e esta, a unidade das diferenças. No Absoluto divino, a radical diferenciação é intrínseca ao próprio conceito divino, por meio da identidade na multiplicidade e da multiplicidade na identidade, na diferença fundamental entre o Pai e o Filho unificada no eterno amor do Espírito. Como mediação sistemática, a História da Filosofia pode ser determinada como a racionalidade mais profunda da História, como a mediação que une e interliga os tempos e as épocas, e a expressão da autodeterminação de toda a realidade na racionalidade absolutamente universal. A triadicidade divina exposta por Hegel na Filosofia da Religião é a estrutura fundamental do mundo, na Pessoa do Pai homóloga à espacialidade do mundo; a Pessoa do Filho homóloga às estruturas e sistemas do mundo e do Universo; e a Pessoa do Espírito homóloga às relações que estruturam o mundo e o Universo.

Para a exposição da passagem da Filosofia do Espírito para o Espírito absoluto, uma referência básica é o círculo dialético que compreende a Filosofia da História e a História da Filosofia, conforme indicamos preliminarmente no silogismo da mediação do Espírito. No capítulo da Enciclopédia das Ciências Filosóficas intitulado Espírito absoluto, a última determinação da Filosofia é a História da Filosofia. Defendemos a inexistência, em Hegel, de uma filosofia pura e uma racionalidade derivada que seria a História da Filosofia. Para o filósofo, Filosofia, História da Filosofia e Sistema Filosófico constituem a mesma coisa. A razão desta identificação 
é estabelecida porque a racionalidade filosófica constitui um todo em desenvolvimento e em diferenciação na sua história racional resultante na autossistematização desse movimento. $O$ sistema filosófico hegeliano pode ser considerado como expressão do movimento de autoconstrução da Filosofia como História da Filosofia, constituída num caminho de intensa energia filosófica determinada por muitos filósofos, sistemas filosóficos, modelos de racionalidade filosófica e formas de totalidade filosóficas, como seria, por exemplo, o conjunto do Idealismo alemão. Não se trata de uma volta ao passado, mas na formulação hegeliana os constructos filosóficos anteriores são traduzidos na figuração atual obtida a partir do exercício de reconstrução e de atualização da racionalidade filosófica como um todo. Hegel escreve sobre esta questão:

\footnotetext{
Segundo esta ideia sustento que a sucessão dos sistemas filosóficos na história é idêntica à sucessão lógica das determinações conceituais da ideia. Sustento que, despojando os conceitos fundamentais que aparecem na história da filosofia de tudo o que respeita à formação exterior da mesma, e à sua aplicação ao particular e assim por diante, se obtêm os vários graus da determinação da ideia no seu conceito lógico. Pelo reverso, tomando o processo lógico, encontra-se nele, nos seus momentos capitais, o processo dos fenômenos históricos. Mas importa saber reconhecer estes conceitos puros no que tem forma histórica (HEGEL, 1986, p. 49).
}

A formulação nos proporciona uma noção acerca da concepção hegeliana de Filosofia como a expressão mais elevada do Espírito absoluto. Nessa plataforma, Hegel identifica Filosofia, História da Filosofia e Sistema filosófico na sua direta relação com a Ciência da Lógica. A concepção hegeliana de filosofia não se restringe à proposta de um filósofo individual, mas diz respeito ao movimento universal de formação da filosofia desencadeada num processo de atualização permanente de todo o pensamento. Nesse sentido, por exemplo, as filosofias de Platão, de Espinosa e de Fichte constituem momentos particulares e diferenciados de um sistema em processo de autossistematização abrangente. Significa dizer 
que cada filósofo e sistema filosófico particular não caracteriza uma doutrina acabada, mas uma expressão de um movimento amplo e complexo. Por esse viés, a sequência do processo de desenvolvimento dos sistemas filosóficos constituídos ao longo da História da Filosofia é semelhante à sucessão das determinações conceituais da Ideia. Assim, por exemplo, à universalidade da Ideia corresponde a noção do ser e da Ideia grega, e, à noção de Deus transcendente, do pensamento medieval. À particularidade da Ideia corresponde a noção de subjetividade moderna, especialmente nas formulações encontráveis em Descartes e em Kant. À singularidade e totalidade da Ideia correspondem os sistemas do Idealismo alemão, em sua tentativa de conciliar a subjetividade e a objetividade, método e sistema, Absoluto e Relativo, etc. Semelhante correlação pode ser obtida na correspondência da universalidade com os sistemas de Kant e de Fichte, a particularidade com os sistemas de Espinosa e Schelling e a singularidade com o sistema hegeliano. Na mesma formulação, a sucessão de sistemas filosóficos na História da Filosofia produz as determinações conceituais da Ideia filosófica, nas mais variadas modalidades de exposição do Absoluto. A Ciência da Lógica não é mais, nessa perspectiva de abordagem, uma ciência pura anterior à sua exteriorização e automanifestação, mas ela constitui expressão do autodesenvolvimento da Filosofia como História da Filosofia. As formas lógicas não estão dadas em seu apriorismo, mas o próprio processo de construção da filosofia produz o conceito e as estruturas lógicas. Caso seja viável qualificar a Ciência da Lógica como uma Metafilosofia, ela é resultado do desenvolvimento conjunto da História da Filosofia que, em sua estruturação global, desenhou um sistema lógico que Hegel sistematizou como Ciência da Lógica. O raciocínio também pode ser invertido na medida em que a Ideia lógica se constitui e se desdobra na totalidade sistemática da História da Filosofia. Dirk Stederoth segue este mesmo caminho:

Como realização do critério de significação para uma Filosofia do Real absoluta - portanto na determinidade da Ideia absoluta - só pode valer para o Espírito Absoluto, enquanto nele não só a Filosofia do Real chega à sua completude, mas também a 
Lógica - as implicações da Filosofia da História no sentido pleno da tese efetivamente retomada, que a História da Filosofia segue o caminho da Lógica; e onde Hegel desenvolve algumas figurações históricas da filosofia enquanto filosofias do real, expondo ultimamente como sistema (STEDEROTH, 2001, p. 72).

Dirk Stederoth tem uma forma peculiar de compreensão e de exposição das relações entre Ciência da Lógica e a Filosofia do real, não realizadas a partir de correspondências conceituais homólogas entre uma e outra esfera. A abordagem é densa porque o filósofo emprega expressões como Filosofia do real absoluta, Ideia absoluta, Espírito absoluto, Filosofia da História e História da Filosofia. Numa primeira aproximação, trata-se de uma Filosofia do real absoluta na perspectiva da Ideia absoluta, exposta no movimento de autoconstrução sistemática da Filosofia em que são conjugadas a racionalidade intrínseca (Ciência da Lógica) e a estrutura global do sistema filosófico esboçado na Enciclopédia das Ciências Filosóficas. O próprio movimento de autoconstrução da filosofia caracteriza um desenvolvimento racional evidenciado na coextensividade entre a edificação da Lógica e do sistema filosófico como um todo. Trata-se da realidade concreta e da História da Filosofia absoluta porque caracteriza um processo sistemático que atualiza todas as formas de pensamento, do processo sistemático universal que produz as determinações estruturais, tais como os sistemas de Fichte e Schelling, e o movimento de interação entre os sistemas que constituem a própria universalidade filosófica. $\mathrm{O}$ Espírito absoluto caracteriza o movimento e a atividade de autodeterminação universal, multidimensional e transversal de todas as esferas do real mediatizadas pela racionalidade absolutamente universal que as perpassa. A universal objetividade, intersubjetividade e interrelacionalidade do Espírito absoluto em permanente movimento de autoconstrução e atualização aparece na dimensão racional do sistema filosófico.

Para uma compreensão mais ampla da noção hegeliana de Espírito absoluto, Dirk Stederoth sustenta a consubstancialidade entre a História 
da Filosofia e a totalidade do Sistema Filosófico de cuja implicação resulta uma Filosofia do Real absoluta. Para esse processo de fundamentação, o sistema da Enciclopédia das Ciências Filosóficas é exposto mediante a dupla figuração da horizontalidade, na sequência da Doutrina do Ser, da Doutrina da Essência e da Doutrina do Conceito; e da figuração da verticalidade, com as determinações da Filosofia do real de Natureza, Espírito subjetivo, Espírito objetivo e Espírito absoluto. Nesse desenvolvimento conjugado, ao longo dessa trajetória, Hegel expõe algumas determinações fundamentais e estruturantes da História da Filosofia, tais como a sistemática do real no Atomismo grego, no Ser de Heráclito e de Parmênides, na determinidade do Absoluto de Espinosa e na determinidade da Ideia na Enciclopédia das Ciências Filosóficas. Nos níveis das determinações da efetividade, representados pela verticalidade da sistemática do real, e dos momentos estruturantes da Ciência da Lógica, representados pela horizontalidade da História da Filosofia, está a intrínseca consubstancialidade entre Sistema e História, entre Lógica e Filosofia do real expostas num movimento integrado. As determinações históricas da filosofia aqui citadas como momentos estruturantes de um desenvolvimento sistemático amplo, estão distribuídas em diferentes espaços conceituais segundo os momentos correspondentes na horizontalidade e na verticalidade, quando a Enciclopédia das Ciências Filosóficas aparece, por exemplo, entre a Lógica do conceito e o espírito objetivo. Nessa progressão, a Filosofia da Religião é a expressão da circularidade absoluta, da absoluta mediação e relacionalidade, da universal implicação entre racionalidade e efetividade, na Filosofia do Real absoluta. Desaparecem as imagens da horizontalidade e da verticalidade e o sistema do Espírito absoluto realiza a suprassunção no círculo universal absoluto internamente constituído pela estrutura e pelo movimento de circularidade e intercircularidade entre os círculos particulares, o que caracteriza o círculo universal absoluto. Angehrn sistematiza esta questão: 
de como a determinação essencial de uma teoria de liberdade. Partindo de dois pontos de vista a serem especificados, o que significa para o Sistema que a sua forma e o seu conteúdo são constituídos no conceito de liberdade. O Sistema é teoria de liberdade, no qual é por um lado Filosofia da História, por outro, teoria do Espírito Absoluto e, por último, teoria da filosofia, ou filosofia que a si mesma se concebe. É demonstrada a unificação real entre o fim do Sistema e a conclusão da História da Filosofia. Num sentido análogo, o desdobramento histórico representa para o conjunto da esfera do Espírito Absoluto momento essencial, no resultado conjunto das instâncias fundamentais a partir de cada uma. A fundamental dimensão histórica do vir-a-ser da consciência do Espírito em si mesmo que na correspondência de História do mundo, História da ciência e filosofia sistemática expressa, há uma congruência entre o conteúdo da História e o conteúdo da Filosofia mesma (ANGEHRN, 1977, p. 420).

Em suma, incluímos um texto extraído do livro de Emil Angehrn (1977) intitulado Freiheit und System bei Hegel. Para o filósofo, a liberdade é a força motriz do sistema filosófico, fazendo da filosofia hegeliana um sistema de liberdade. A Teoria da liberdade é desenvolvida por meio de vários momentos estruturantes do sistema hegeliano, tais como a Ciência da Lógica, a Filosofia do Direito e a Filosofia da História. Merecem destaque as determinações do Espírito absoluto, a arte, a religião e a filosofia. Depois da exposição linear do conjunto da filosofia, o comentarista de Hegel expõe um capítulo final que trata do Sistema de Liberdade, como uma passagem para o sistema como um todo. Nesse aspecto, o sistema filosófico é considerado como uma Filosofia da História, na dupla perspectiva de que a filosofia aparece como uma intepretação crítica e uma idealização da História, e no sentido do processo histórico e sistemático da própria filosofia. O sistema filosófico é uma Filosofia da História porque integra sinteticamente em sua exposição vários sistemas desenvolvidos ao longo da História e reintegra na atualidade do pensamento múltiplas formas de pensamento. Trata-se de pensar a filosofia na perspectiva de um único sistema filosófico ramificado na multidimensionalidade de 
formas de sistemas particulares em meio aos quais surge uma única filosofia sistematicamente organizada. Como uma fundamental e universal Filosofia da História e Filosofia do Espírito, o sistema filosófico hegeliano sistematiza numa única exposição as principais estruturas da História da Filosofia atualizadas pela mediação da História, cujos momentos fundamentais são expostos no presente artigo. O sistema também é uma teoria do Espírito absoluto como uma autoconsciência do Absoluto no homem e no pensamento filosófico, e especialmente uma sistematização do pensamento filosófico e humano do Absoluto, da qual emerge a autoconsciência filosófica do homem. O sistema filosófico é suprassumido numa teoria do Espírito absoluto ao sistematizar de forma integradora e atualizada as principais formas de compreensão do Absoluto ao longo do tempo. Como uma Teoria do Espírito absoluto, o sistema filosófico hegeliano trata do Absoluto como totalidade em autodesenvolvimento, filosoficamente pensado na estrutura macrossistemática das mediações entre os círculos do sistema. O sistema filosófico também é uma Teoria da Filosofia, de uma filosofia que a si mesma se concebe, na perspectiva da ressignificação e ressistematização do conjunto da filosofia. Nessa posição coincidem o Sistema Filosófico e a História da Filosofia, história da ciência e filosofia sistemática, conteúdo da História e conteúdo da Filosofia. A concepção hegeliana de Espírito absoluto tem como objeto a compreensão filosófica do Absoluto traduzida como um momento constitutivo do próprio Absoluto, e o Absoluto como totalidade absoluta do ser humano, numa implicação dialética entre a finitude e a infinitude, entre relatividade e absoluticidade. Ao mesmo tempo, o Espírito absoluto não é apenas teórico, mas também real e efetivo, como totalidade e interconectividade absoluta de tudo, resultando em um sistema relacional de todos os sistemas relacionais, como uma intersubjetividade absoluta. 


\section{Considerações finais}

O sistema filosófico hegeliano, nas múltiplas relações entre a Ideia filosófica e as esferas de Lógica, Natureza e Espírito e as inter-relações delas, pode ser lido na perspectiva epistemológica atual da interdisciplinaridade. $\mathrm{O}$ artigo procurou evidenciar os nexos estruturais entre as regiões lógicas e epistemológicas da Ciência da Lógica, da Filosofia da Natureza e da Filosofia do Espírito, com a finalidade de proposição do pensamento hegeliano esboçado na Enciclopédia das Ciências Filosóficas como um sistema complexo de interdisciplinaridade. Mesmo no contexto atual em que a categoria epistemológica, acadêmica e curricular da interdisciplinaridade é tão difundida, ainda não apareceu uma formulação tão complexa e articulada como o modelo hegeliano. Como estratégia metodológica de elaboração do artigo tomamos como referência textos significativos de Hegel, constantes na Introdução da Enciclopédia das Ciências Filosóficas, na Introdução da Filosofia da Natureza, na Introdução da Filosofia do Espírito e os parágrafos finais que tratam do Espírito absoluto. Não se trata apenas da passagem de uma esfera para a outra, mas a interdisciplinaridade filosófica caracteriza os movimentos estruturantes de inter-relações globais entre as esferas filosóficas.

A mais ampla configuração de interdisciplinaridade no sistema hegeliano é entre a Ideia filosófica e as particularidades das esferas filosóficas de Ciência da Lógica, de Filosofia da Natureza e Filosofia do Espírito. Em outras palavras, trata-se das relações entre o denominado círculo dos círculos e os círculos particulares. A Ideia é o círculo mais amplo que compenetra exteriormente o sistema filosófico, estabelece a significatividade filosófica a todas as estruturas do real e promove a transversalidade interesférica enquanto dinamismo sistemático de desenvolvimento. Como uma espécie de universalidade filosófica, penetra nas esferas filosóficas particulares na forma de uma transmigração epistemológica e lógica que interliga sistematicamente as esferas numa estrutura de interdisciplinaridade multidimensional. Por outro lado, para ultrapassar qualquer 
forma de apriorismo, no movimento inverso das relações interesféricas produz a inteligibilidade da Ideia filosófica como significação universal. Nessa configuração, cada círculo não é meramente uma particularidade, mas a autoexpressão da totalidade do sistema filosófico na configuração do sistema da Lógica, do sistema da Natureza e do sistema do Espírito.

\section{Referências}

ANGEHRN, E. Freiheit und System bei Hegel. Berlin: Walter de Gruyter, 1977. CHARDIN, Teilhard. O Fenômeno Humano. São Paulo: Editora Cultrix, 1995. FLÓREZ, Ramiro. La dialéctica de la historia en Hegel. Madrid: Gredos, 1983. HEGEL, G. W. F. Enciclopédia das ciências filosóficas em compêndio (1830). Tradução: Paulo Meneses. São Paulo: Loyola, 1995a. 3 v.

HEGEL, G. W. F. Enzyklopädie der Philosophischen Wissenschaften im Grundrisse. Hamburg: Felix Meiner Verlag, 1999.

HEGEL, G. W. F. Vorlesungen über die Geschichte der Philosophie. Frankfurt am Main: Suhrkamp, 1986. 3 v.

HEGEL, G. W. F. Vorlesungen über die Philosophie der Religion. Der Begriff der Religion. Hamburg: Felix Meiner, 1993. https://doi.org/10.1017/ $\underline{\text { SO263523200007217 }}$

HEGEL, G. W. F. Wissenschaft der Logik. Frankfurt am Main: Suhrkamp, 1993. HEGEL, G. W. F. Wissenschaft der Logik. Hamburg: Felix Meiner, 1999. HÖSLE, V. Hegels System. Der Idealismus der Subjektivität und das Problem der Intersubjektivität. Hamburg: Meiner, 1998. https://doi.org/10.1353/ hph.1989.0073

HÖSLE, V. O Sistema de Hegel. O idealismo da subjetividade e o problema da intersubjetividade. Trad. De Antônio Celiomar Pinto de Lima. São Paulo: Loyola, 2007.

JARCZYK, G. Système et Liberté dans la Logique de Hegel. Paris: AubierMontaigne, 1980.

KRONER, Richard. Von Kant bis Hegel. Tübingen: Mohr Siebeck, 1961. 
LAKEBRINK, Bernhard. Die Europäische Idee der Freiheit. Hegels Logik und die Tradition der Selbstbestimmung. Netherlands: Leiden E. J. Brill, 1968. https://doi.org/10.1353/hph.2008.1348

LIMA VAZ, H. C. Antropologia filosófica II. São Paulo: Loyola, 1992.

STEDEROTH, Dirk. Hegels Philosophie des Subjektiven Geistes. Ein Komparatorischer Kommentar. Berlin: Akademie Verlag, 2001. https://doi. org/10.1524/9783050047676

THEUNISSEN, Michael. Hegels Lehre vom absoluten Geist als theologisch-politischer Traktat. Berlin: Walter de Gruyter, 1970. https://doi. org/10.1515/9783110841770

TOPP, Christian. Philosophie als Wissenschaft. Berlin: Walter de Gruyter, 1982. 